\title{
Technology storylines: A narrative analysis of the rural education research
}

\author{
Elizabeth S. Wargo \\ Jeff Simmons
}

\begin{abstract}
This piece offers a systematic review of rural (P-12) education technology literature. Drawing upon a social change frame (Ogburn, 1922), current rural education technology research within the subfield is collected, examined, and synthesized. Findings explicate that methodological diversity is a strength; however, some populations (e.g., middle school teachers) have thicker coverage than others (e.g., high school students). Additionally, many studies lean on rhetorical structures about what could and should be happening in rural schools, rarely delving into the how's and whys associated with actual technology use in rural contexts. The piece concludes with a call for scholarship which assists in shifting power structures to support rural schools in their efforts to work with technology for the betterment of rural students and communities in place.
\end{abstract}

Rural education is entangled with technology. The use of technology as part of rural schooling in the United States is now commonplace, especially in light of COVID-19 campus closures. Look in any classroom and you will see objects which serve as a mental reminder that rural students and educators now have at least some access to global networks of information, even in the most remote and rural schools.

Such an explosion of technology use amplifies and complicates issues of rural education equity and access. Rural education contexts are always changing and so is technology. Digitization of processes is pervasive, and the use of technology is "an integral, sometimes invisible, aspect of rural life" (Roberts et al., 2016, p. 372). As such, issues of rural educational equity are now intertwined with technology and must be made visible.

Rural locations have less broadband than nonrural locales (FCC, 2020). Despite the federal ERate program, which allocates billions to telecommunications entities, many rural schools still do not meet the Federal Communications Commission connectivity goals. As the National Association of Rural Education (NREA) points out:

Rural areas have been slow to benefit-in-full from the technological advancements and many lack access to sufficient bandwidth to support whole-school online access simultaneously. Technology offers promise but cannot be assumed as a solution for all rural schools in the short-term.

One of the ten research priorities set by the 20162021 NREA is technology integration that benefits rural schools; however, little synthesis of research associated with this priority exists (Bruwelheide, 1984; Hannum, 2007; Howley \& Howley, 2009; Vasquez \& Serianni, 2012 being exceptions; however, none of these studies were specifically limited to rural settings). This void is not surprising given synthesis of dispersed rural education research findings is scarce in general. Lack of comprehensive synthesis of rural education research impedes researchers, practitioners, policymakers, and advocates from making use of "the findings of research to inform their craft" (Coladarci, 2007, p. 6).

This review of research aims to extend discourse by collecting, examining, and synthesizing published rural education $(\mathrm{P}-12)$ technology research from 1980 to 2020 . In doing so we: (a) "take stock" of the empirical literature on education technology in rural schools, (b) synthesize the state of rural-related education technology research, (c) revisit critical discourse in the field about education change and (d) provide a sociologically informed foundation for future research. The research questions which focus this inquiry are:

1. What literature exists within the current body of empirical U.S. rural education (P12) research about technology?

2. What populations and topics, by whom and how, are addressed?

3. What issues, topics, and theoretical perspectives are missing?

4. How is technology socially constructed in the current body of rural education literature?

Questions 1-3 are designed to assist with descriptive synthesis and to further assist in narrowing results for a deeper interpretative synthesis to answer question four. By asking questions two and three, attention is paid to participant demographics, research approaches, and theoretical paradigms using the notion of de Certeau's (1984) "expanses of silence" which serves to assist inquiry given "digital technologies are now entwined deeply with the politics of contemporary education" and far from a "...benign, neutral presence in education" (Selwyn, 2015, p.248). 


\section{Technology and Rural Schooling: A Brief Historical Overview}

In 1958 the National Defense Education Act allocated money for technology in schools with the aim of improved achievement; a trend that has increased ever since (Anderson \& Becker, 2001; NCES, 2019; FCC, 2020). With increased schooling criticism and the spread of personal computing technology came a common mindset that education could be transformed by computers (Brockmeier et al., 2005). For example, the 1983 "A Nation at Risk" federal report stressed the need to systematically integrate technologies into education, and the 1994 "Goals 2000: Educate America Act" positioned states to receive funding for technology planning. No Child Left Behind (NCLB) legislation increased reporting and assessment and linked technology infrastructure and training funding with school improvement goals (Cullen et al., 2006; Reeves, 2003). All examples of federal policy and communication further catalyzing the use of education technology in rural schools.

In 2010 the U.S. Department of Education's Transforming American Education Learning Powered by Technology plan stated, "Technology is at the core of virtually every aspect of our daily lives and work, and we must leverage it to provide engaging and powerful learning experiences and content" (p. xi). The 2015 Every Student Succeeds Act (ESSA) federal policy, which marks an increase in the power shift to local states and districts, does not specifically outline technology programming, like previous federal policy (e.g., Enhancing Education Through Technology Program). It is embedded in the flexible block grant (Title IV, Part A) program (ISTE, 2016, p. 3). The 2017 National Education Technology Plan Update: Reimagining the Role of Technology in Education describes learning as enabled by technology. More recently, the use of technology to support distance learning (and what some refer to as crisis schooling, (e.g., McLeod and Dulsky, 2021) mostly online has received heavy rhetorical emphasis as policymakers and practitioners attempt to grapple with providing educational opportunities alongside social distancing measures associated with the COVID-19 pandemic. In rural contexts, where access to high-speed broadband is not universal, such emphasis potentially disadvantages rural learners providing further need to examine policy, practice, and research at the intersection of educational technology and rural schooling.

\section{Theoretical Framework}

The theoretical framework for this review is broadly rooted in social change theory (Ogburn, 1922). Using this frame acknowledges technological progress and social responses to such progress involved in examining research articles as documents that contribute to narratives about technology in rural education. Theorizing social change associated with technology offers an entry point into issues of equity, power, and justice. Technological change affects rural schools as social institutions in ways that are far more complex (economically, politically, culturally) than they may appear at first glance.

Recognizing the complexity of this technical and sociological entanglement then, technology (broadly conceptualized in this study) refers to computing and related information communication technologies associated with rural education. Although some might argue such a broad conception of something as complex as technology might "deny the weight of technology," Sassen (2002) points out, such conception makes room for more "analytic categories" allowing us "to capture the complex" (p. 366). By systematically reviewing rural education research, this review attempts to capture the complex intersection of educational technology and rural schooling by providing a route to critically examine how technology is covered in rural education research.

This inquiry intentionally seeks to broadly map and examine the entanglement of things and people (Pickering, 1995), as these objects, tools, and practices exist in changing contexts that are constantly redefined (Leu et al., 2015). Bourdieu's (1994) construct of "epistemic reflexivity" as a theoretical construct guides our scholarly reflection as "an 'impartial spectator' who seeks to understand for the sake of understanding" (Bourdieu,1990, p. 31). By embracing a "sociology of sociology” (Bourdieu \& Wacquant, 1992) we aim to illuminate practices, assumptions, and structures within the research about educational technology. It too allows for "work with (and work around) the uncertain and often contradictory realities of technology and education", by explicitly looking beyond the "here and now" and technocentric focus of research (Selwyn, 2015, p. 253). Additionally, Corbett's (2015) call for "stronger engagement of the conceptual tools of sociology and contemporary social theory in rural education scholarship" (p. 9) is embraced.

\section{Methodology}

This systematic review examines current scholarship at the intersection of U.S. rural schooling (P-12) and education technology to renew discourse and provide guidance for future education technology research in rural contexts using a narrative synthesis approach. According to Popay et al. (2006), a narrative synthesis is "an approach to the systematic review and synthesis of findings from multiple studies that relies primarily 
on the use of words and text to summarize and explain the findings of the synthesis" (p. 5).

Studies centered on education outside of rural U.S. contexts were not included in this review. Using an epistemic reflexivity paradigm, drawing on ethnographic content analysis (Altheide, 1987), this review focused on peer-reviewed, published studies about education technology in U.S. P-12 rural education.

Using a similar analytic approach to the one Burton, Brown, and Johnson (2013) used to examine rural teachers; narrative threads within the research articles which depict educational technology in rural education $(\mathrm{P}-12)$ contexts are examined. Like Burton and colleagues, ethnographic content analysis (Altheide, 1987) is used to review research articles as "rhetorical documents" to consider "the ways these storylines contribute to a broader social and cultural narrative about... rural schools" (Burton, Brown, \& Johnson, p. 2) and the extent to which existing literature deals with what Selwyn (2015) described as the "political, economic, social, cultural, and historical 'messiness' of technology and education" (p. 249). As Lynch (2015) points out:

Stories play an important role in what meaning we make from the use of technological artifacts in educational settings, serving as agents in what we authorize as valuable and what we see as possible. This is as true for the stories produced by researchers as it is for stories told by those teachers, parents, and students who participate in our research. (p. 1)

\section{Source Identification}

Given personal computing and archiving of journal articles in academic search engines both emerged at the beginning of the 1980s, 1980 was the starting point. Due to the rapid nature of technology development, the first author started her search by conceptualizing educational technology in the broadest sense by including the terms "ruralschool/education" AND "technology," "computer(s)," "ICT," as well as the more contemporary terms of "SMART/mobile- phone," "tablet," "Internet," "virtual," and finally "digital" in the academic search engines JSTOR and ERIC (EBSCO). Reviewing the search results: titles,

Table 1

Number of Results Reviewed by Decade

\begin{tabular}{lc}
\hline \multicolumn{1}{c}{ Decade } & Reviewed results \\
\hline $1980-89$ & 12 \\
$1990-99$ & 25 \\
$2000-2009$ & 19 \\
$2010-2020$ & 25 \\
\hline Total & 83 \\
\hline
\end{tabular}

abstracts, and in a small number of cases, the full text of the article, a number of sifting criteria.

All non-peer review articles, books, and documents were excluded. In part, this was done to ensure alignment with the aim of this piece being the review of scholarly literature. Additionally, all non-English or Spanish pieces or works focusing beyond the United States were excluded. This collection process yielded 111 articles.

Additionally, the full collection of the Journal of Rural Education Research and The Rural Educator were searched to assure full coverage from the field's prominent journals and cross-referenced findings with the initial search and subsequently adding 18 articles that did not appear in the initial search. A total of 129 articles were included in the collection for initial analysis.

\section{Initial Source Analysis and Mapping}

The analysis and interpretation of rural studies included in this review are informed by what Farmer (1997) stated: "there is no singular or multifaceted definition that will suffice to satisfy the research, programmatic, and policy communities that employ the concept" (p. 632). Yet, to select appropriate texts to match the aims of this study, we embrace paying close attention to the "rurality of the phenomena" within each work. Coladarci (2007) points out, "regardless of methodological persuasion, rural education researchers must offer vivid contrasts between rural and nonrural contexts in order to establish the rurality of the phenomena they putatively uncover" (p.3). Building upon Coladarci's (2007) "rural warrant" argument (p.3), other scholars have pointed out the need to carefully attend to rurality (Biddle et al., 2020; Corbett, 2017). For these reasons, articles that did not foreground a rural context were removed leaving 83 articles. Of special note is the diversity of study settings. Not surprisingly, 46 of the 83 studies were published in three rural-focused journals (JRRE, The Rural Educator \& Rural Special Education Quarterly). The majority of studies meeting the criteria not within these three journals focused on distance education for teacher professional development, many at the middle school level associated with science education.

Table 2

Methodology Coverage

\begin{tabular}{lc}
\hline \multicolumn{1}{c}{ Method } & Reviewed results \\
\hline Mixed & 7 \\
Conceptual & 29 \\
Qualitative & 24 \\
Quantitative & 22 \\
\hline Total & 82 \\
\hline
\end{tabular}


Table 3

Coverage

\begin{tabular}{lc}
\hline \multicolumn{1}{c}{ Participants } & \multicolumn{1}{c}{ Settings } \\
\hline Students & (2)ES, (7)MS, (5)HS, (5)District \\
Teachers & (5)ES, (12)MS, (10)HS, (11)*District \\
Administrators & (5)District \\
Support Staff & (3)District \\
Parents & (3)District \\
\hline
\end{tabular}

*9 of the reviewed articles reported findings about more than one type of participant group (i.e.

observation of teacher's technology usage and student achievement, student and parent perceptions)

The descriptive synthesis (as shown in Tables 1-3) provided the groundwork to conduct the interpretative synthesis. This initial analysis aligned with the first three research questions reveals two overlapping areas of coverage that dominate the field to date: (a) distance education for student learning and or teacher professional development $(\mathrm{n}=35)$, and (b) technology integration associated with in-person schooling $(n=52)$. Additionally, 29 conceptual pieces broadly focused on technology and changes to rural schooling span both areas.

After synthesizing this larger body of research, additional inclusion/exclusion criteria were applied, removing articles largely conceptual in nature (those having no clear method section) to ensure a tight focus on education technologyrelated research, leaving 52 articles included in this review, to answer the fourth question: How is technology socially constructed in the current body of rural education literature?

To support a valid and reliable review, two random blind samples of 10 of the 52 studies $(n=20)$ were selected and notes for consistency were compared about method and content (Fink, 2019) by the first author. Although notes indicated consistency, it is important to acknowledge, like Burton et al. (2013), the constructivist role in this narrative analysis. We did not attempt to judge the accuracy of the storylines, instead focused on identifying what emerged during analysis as storylines from published rural research concerning educational technology.

Drawing on Burton et al. (2013), using an inductive approach to "discover meaning and to achieve understanding" (Benner, 1994, p. 10), each article was then reviewed by the first author two (or in the case of the 20 articles included in the blind sample, three) times for patterns that emerged about education technology as part of rural schooling (see Appendix A). The way authors described rural settings and characters was noted paying particular attention to "the descriptions of the characters and their depictions as protagonists or antagonists" (Burton et al., 2013, p. 4). Previous scholars (e.g., Hannum, 2007) have pointed out the tendency for the technology itself to be positioned as the protagonist when using language such as "When Computers Teach" (Hannum, 2007, p. 5). Within this review, many rhetorical structures also tended to do the same. Such as Collier et al., (2017) who stated, "multimedia can effectively facilitate professional development to foster collaborative relationships with families" (p. 150) when summarizing previous research. Within these narratives, teacher educators and rural teachers were often positioned as the antagonists or the reasons why such "desirable" outcomes associated with using technology were not yet a reality. For example, McGinnis et al.'s (1996) stated:

Clearly, the implications for science teacher educators are that rural teachers of science need to be more cognizant of how to implement computing technologies to aid in management and curricular planning, and instructional applications that include Telecommunication. (p. 118)

Although such language was common, not all authors position rural settings or characters as deficits, instead providing a more nuanced understanding and alternative explanations about the complexity of technology, rural education, and the intersection of the two. For example, Howley and Howley (1994), who like McGinnis et al., (1996) also explored teachers' perceptions of access and use in a state-wide setting (West Virginia), positioned the "private-enterprise" of "telecommunications networks" and state mandates "requiring teachers to learn and make use of two specific commercially packed software systems [original emphasis] as working "against" rural teachers" ability to make "wise use of technology" (p. 19). Three storylines emerged showcasing how authors constructed use of technology within the plot of each of their studies.

\section{Education Technology Storylines}

Three overlapping storylines emerged from the narrative analysis of the 52 articles reviewed: (1) technology as a catalyst for change, (2) rural equity 
reasoning, and (3) the only choice. Within these three storylines, the notion of rural context (setting) was constructed by scholars as both physical place (e.g., technology integration in a rural science classroom), online space (e.g., distance education for student learning and or teacher professional development), and a blend of the two. For example, Ruopp et al. (1993), reported on science teachers' use of online forums to collaborate about technology-infused science projects taking place in rural regions. Despite variations in scope, from "issues of learning" (Selwyn, 2010, p. 66) in a single classroom between a few individuals (e.g., Singer et al., 1986, focused on one paraprofessional working with one rural student) to those focused more broadly (e.g., Schafft et al.'s, 2006 exploration of technology infrastructure, school district improvement, and community development), researchers rhetorically linked language about "technology" with "change".

\section{Technology as a catalyst for change}

The first storyline, technology as a catalyst for change, persisted across the vast majority of studies. Within this dominant storyline, authors described access to and use of technology toward changing a myriad of aspects of rural teaching, learning, and schooling as they described the "power" and "potential" of technology. Baker (1986) expressed, "few educators would argue that computers are just another fad that will wind up on the shelf as have so many previous innovations" (p. 1). In one article (Krall et al. 2009) reviewed, the word "change" was used 50 times. As authors depicted educational technology as something that "could", "should", and "would" shift different aspects of rural education they perpetuated the notion that such a change was inevitable. Most researchers drew on demographic and geographic aspects of rurality (Reid et al., 2010) to describe access and/or use of technology, while few attended to cultural constructs (Pyles, 2016; Staley, 2017; and Wake, 2012 being exceptions). Often researchers used comparative language by describing access to and use of technology in nonrural schools when discussing why their study was needed.

\section{Technology access and/or use}

Logically, earlier articles reviewed reported limited access to technology for rural students (Baker, 1986; Stammen, 1992), teachers (Howley \& Howley, 1994; Alexander, 2003), support staff (Wirth et al., 1983), and pre-service educators (Lahman et al., 2006). However, the construct of exploring access and/or use persisted throughout the four decades of research reviewed as authors explored the same construct with newer technologies (e.g., Kalonde's, 2018 exploration of
iPad usage). The degree to which authors stressed the urgency of acquiring and using computing technology varied. Griswold (1984) highlighted that rural schools have less access to instructional computing and how without computer literacy those in rural areas would be "seriously polarized" (p. 11). While Baker and Hall (1994), Stammen (1992), and Howley and Howley (1994) offered examples more in line with McGinnis et al., (1996) who used softer language when stating, "teaching science students with microcomputers and educational software can result in desirable cognitive and affective learning outcomes" (p. 111). In many cases, researchers highlighted the need for educators to become aware of "technological possibilities" and develop capacity to leverage technology to access professional development as well as integrate technology within lessons.

One of the more notable pieces reviewed was the 6-year, multi-site NSF Labnet project which supported rural science teachers' use of telecommunications networks to support each other to "think about their work, setting the direction, and help each other change" (Ruopp et al., 1993, p. 2). In 1993, Ruopp and colleagues described, "The microcomputer is having an increasingly powerful influence on the classroom" (p. 3) as they drew attention to how educational networks are formed and supported. Similarly, Barker and Hall (1994) stated, "The proper use of these technologies seems to broaden student learning opportunities and, at the same time, connect teachers with new resource materials and experts across the country" (p. 126). Although what exactly authors described as changing with technology, as well as how they positioned rural actors varied considerably, a common storyline that existed in most of the articles reviewed was associated with future readiness or modernity. Barker (1986) described, "To help ensure student preparation for the future... The importance and necessity of placing added emphasis on computers in education seems self-evident" (p. 1). A few years later he and a colleague offered "The benefit to rural schools is obvious. The traditional barriers of remoteness and geographical isolation are bridged by today's telecommunications technologies" (Baker \& Hall, 1994, p. 128). Like Barker and Hall (1994), most researchers discussed the positive impacts of technology use.

\section{Use with impact}

In the mid-'90s the first storyline expanded to include notions beyond binary questions of access and use toward evaluating the impacts of such access and use. Most of these studies were "learning science" (Selwyn, 2010, p.67) focused as researchers aimed to evaluate the use of technology. As newer technologies emerged, 
scholars looped back to inquire about access and use combined with impact. Kalonde (2018) described, "specific studies focusing on the use of iPads are extremely limited because the devices were only introduced less than seven years ago (2010)" (p. 27). Within their evaluation of the impact of technology use and user perceptions, Krall et al. (2009) used variations of the word "improve" 21 times with statements such as, "distance learning course for improving their content knowledge and learning content through this [distance] mode" (p. 175).

Like Krall et al. (2009) other authors offered similar examples of their hopes for technology to assist rural students (e.g., Naizer et al., 2014), teachers (e.g., Hawkes \& Good, 2000), support personnel (e.g., Singer et al., 1986), and parents' (e.g., Laho, 2019) as means for improvement. In this sense, the authors not only forwarded the first storyline about technology affecting change but explicitly linked such change to improvement. Many of these improvement-oriented studies highlighted the potential for educators to connect with each other (e.g., Cifuentes et al., 2011; Collier et al., 2017; Hawkes \& Good, 2000; Hunt-Barron et al., 2015; Ruopp et al., 1993) or with teacher (e.g., Cady \& Rearden, 2009; Ruopp, 1993), paraprofessional (e.g., Singer et al., 1986), or psychologist (e.g., Lahman et al., 2006) to connect to training from afar. Often, educators were positioned as the characters moving the storyline forward as the protagonist such as Tyler-Wood et al. (2018) who stated, "Teachers play significant roles in the effective implementation of students' technology-enhanced learning" (p. 2).

Several researchers discussed how interactions between rural actors might influence technology use, such as Stammen (1992) who positioned school administrators as the protagonists when reporting their thoughts about new technology projects and how they play a role in reducing the barrier of "computer anxiety" (p. 27) of the teacher who he positioned as antagonists. Some of these impact-oriented studies found improvements such as Collier et al., (2017) who found "technology was a key component" (p. 148) to support rural teacher professional development, while many others described finding minimal or no improvement (Cady \& Rearden, 2009).

They were not alone in stating their hopes for improvement alongside technological change regardless of their findings. Others, too, shared their hopes that improvement would be realized as soon as technologies developed further. Krall et al. (2009) wrote, "As the availability of high-speed internet services increases... Web-based components of the course... can become more accessible" (p. 184).

Many times, descriptions of teaching and learning improved by technology discussed notions of reducing isolation (e.g., Cady and Rearden, 2009, Powers et al., 2020). Narratives such as these exemplify how many researchers described deficits as something which could be overcome with technology. This emerged as the second storylinerural equity reasoning.

\section{Rural Equity Reasoning}

The second storyline, rural equity reasoning, largely emerged in how authors discussed rural schooling challenges. Stammen (1992) described the "problems and barriers... which impede the use of technology" (p. 25). Many researchers used nonrural comparison language to introduce their study as they highlighted what was lacking in rural contexts such as: external support (e.g., Hawkes et al., 2002), internet infrastructure (e.g., Wargo et al., 2021; Kalonde, 2018; Monhardt \& Monhardt, 1997), funding (e.g., Barker, 1994; Plopper et al., 2013), resources and training (e.g., Singer, 1986; Plopper et al., 2013), administrative support (e.g., Irvin et al., 2010, 2012; Richardson \& McLeod, 2011), and changes in perceptions and behaviors of teachers (e.g., Cullen et al., 2006) and students (e.g., de la Varre et al., 2014).

Howley and Howley (2009) noted "technical problems, organizational capacity limitations, ideological perspectives, and systemic features of school districts tend to impose serious constraints... efforts to integrate technology fully and effectively" (p. 5). Many authors theorized how technology might help overcome a lack of resources. For example, Plopper et al. (2013) stated, "Lack of funding, lack of teacher training, and lack of permission from the administration also were the three reasons provided... for not using iPods" (p. 60). Their work also forwarded the notion that "despite administrative and financial barriers" (p. 64) students could use their own devices such as cell phones as part of their educational experience. Hannum et al., (2009a) described, "financial and human capital constraints" such as how, "Many rural schools experience difficulties attracting and retaining teachers for a variety of reasons including lower salary levels." ... and "difficulties offering a comprehensive curriculum that includes upperlevel courses, advanced placement courses, and vocational courses" (p. 1). Others discussed the "need to use and to effectively capitalize on distance education in order to overcome challenges they [rural school districts] may face (e.g., teacher shortages, difficulties recruiting certified teachers, teaching subjects outside of their certification)" (Irvin et al., 2010, p. 76).

How authors approached narratives about setting varied from brief mentions of a classroom within a school holding a National Center for Education Statistics (NCES) rural label (e.g., Watson et al., 2011), to those explicitly exploring 
elements of rurality throughout, such as Staley (2017), Pyles, (2016) and Wake (2014), who positioned technology as something to be leveraged to deepen student learning about their rural identity and community.

The notion of isolation received heavy rhetorical emphasis in many works reviewed. As researchers drew on geography and demography, they furthered the notion that access and use of technology could provide what was missing from "rural social spaces" (Reid et al., 2010). Many researchers portrayed external factors such as policymakers and preparation program faculty as not providing adequate support, resources, or training within this rural equity storyline. For example, while examining technology facilitation in rural schools Hawkes, Halverson, and Brockmuller (2002) described, "Current graduate programs in instructional or educational technology, computer science, or information systems are rarely compatible with the remoteness of rural environments" (p. 169). One group of studies (especially Cullen et al., 2006 and Cady and Rearden, 2009) within this storyline directly spoke to the notion of technology intertwined with policy more than most which explored highly qualified teacher certification language associated with federal NCLB policy. Several authors noted rural teachers are more professionally isolated and many rural schools have a hard time recruiting and retaining those that are highly qualified and certified (Cady \& Reardon, 2009; Hunt-Barron, et al., 2015; Krall et al., 2009; Summerville \& Johnson, 2006).

Other researchers discussed barriers associated with the perceptions and behavior of rural (internal) actors about technology (e.g., Griswold, 1984; McGinnis, 1996; Kalonde, 2018), some acknowledging policy (e.g., Howley and Howley, 1994) or community context (e.g., Howley et al., 2011; Shaft et al., 2016) more than others. Later works forwarded this notion. These works are important to consider in light of the final storyline, the only choice.

\section{The Only Choice}

The final storyline, the only choice, was present in fewer articles; however, how authors positioned technology as the only choice explicates a construct deserving attention. In this crosscutting storyline, researchers exposed a more nuanced view elevating the notion that rural learners have less opportunity than those in nonrural places. Hunt-Barron et al., (2015) expressed, "For some rural school districts, digital tools may be the only way to bridge the physical distance and develop the long-term partnerships with professional development providers" (p. 12).

Distance learning, opposed to technology integration, studies within this review that discussed economies of scale (e.g., Hannum et al., 2009a) associated with this only choice storyline. Similarly, others (e.g., Elam et al. 2012; Irvin et al., 2013) also furthered the notion that technology could provide access to curriculum rural learners would otherwise not have. Most recently, Powers et al. (2020) discussed how one-to-one device programs might provide access to individualized learning virtually with the language of outsourcing. They described:

This could give these students access to courses and individualized learning opportunities that smaller districts might not have the resources to provide. These distance learning resources include courses that are accelerated, remediated, or unavailable in smaller districts. Public funded virtual schools and non-profits such as the Khan Academy might help fill these gaps (p. 71)

Counter to these notions, Mann et al. (2016) found not only did students underperform in cyber charter schools, as well as how such choice may negatively impact neighboring small rural schools. Two decades previously, Howley and Howley (1994) warned, "A privately controlled "information superhighway" is not likely to take much account of local circumstance, not in the modes of access, the variety of services offered, nor the type of information ultimately accessible" (p. 21) illustrating the need to critically consider the notion of rural education equity alongside technology, particularly when the digital choice is the only choice.

\section{Discussion}

Although we are pleased to report much research progress has been made to inform rural education practice, policy, and research in the past three decades about technology, we cannot help but start this section with a word of caution given the three dominant storylines which emerged from this review. These storylines about rural education intertwined with technology depicted largely positive insights. In some cases, although extreme, the tone presented could even be described as toxically positive as researchers focused more on what they wanted technology to do instead of "what it actually does" (Hess, 2018). This is problematic because as Kalonde (2018) pointed out, "In schools today, there is a massive push to integrate technology throughout the educational process, however there's little consistent documented evidence of its success" (p. 27), which is similar to the sentiments about technology in schools acknowledged by non-rural scholars (e.g., Cuban, 2001).

The sequence researchers used while weaving pro-technology narratives were quite similar despite focusing on different populations and types of technology. The sequence often followed a 
three-part progression. First, researchers would start their plot with language associated with the first storyline (technology as a catalyst for change) as they described the promise of technology (general or specific). Next, they would attach meaning to how the technology might be used as part of rural schooling as they described the aims and questions guiding their research. Finally, they would discuss their findings as they made arguments associated with the need for more or better technology and changes to rural practice and policy. Although there is nothing inherently wrong with each study individually (remember this was not our aim to judge the accuracy of any particular study), when viewing these studies as a combined body of research, large gaps between what authors reported as possible exist between what they reported as the actual.

Many researchers offered language which could be described as "not there yet" as they discussed their findings and the need for more technology. Acknowledging what Howley and Howley (1995) previously stated: "Technology is a form of process, and for us, education is substance: ideas, intellectual content, and emotional meaning" (p. 126) there is much scholarly work still to be done. Although "not there yet" style messaging may bring hope, it is not enough to assure technologies are being created, accessed, used, and reused in ways that forward sustainable social, economic, and environmental futures for rural education serving specific and unique communities.

The rural research reviewed demonstrates how researchers can illuminate the potential of technology to improve specific aspects of rural education (i.e., student learning and how technology can be used to efficiently spread limited human resources); however, many of these works also mentioned complex social, organization, or financial challenges. For example, the distance education studies reviewed indicate rural schools nationally can provide a comprehensive curriculum including advanced courses by offering courses online (Hannum et al., 2009a); yet, rural students, who are used to close relationships with their teachers, may find online courses challenging (de la Varre et al., 2010; Irvin et al., 2009) and be less prepared to take online classes than non-rural youth (Irvin et al., 2012). Within this review, this series of studies about distance education in rural education (de la Varre et al., 2010; 2011; 2014; Hannum et al., 2008; 2009a; Irvin et al., 2009; 2010; 2012) was the only group of studies that seemed to further specific inquiry about a certain aspect of education technology in rural education from access and use, towards questions of impact and optimization. We have no doubt that some tighter groups of studies related to narrow aims associated with particular content exist (e.g., distance math teacher education) that can inform the rural field; however, focusing on the "math" or the "distance" is not enough. This series of works exemplifies how new technological methods and practices may solve some rural education challenges, but they may also create new ones. For example, for students to be successful new types of technical, social, and academic support are necessary. Dropout rates in online courses, especially for certain student populations, are high (Morris et al., 2005), presenting questions about how such online-only options may be disserving the most vulnerable rural youth.

Dolan's (2016) K-12 research review highlighted "the complexities of the evolving digital divide" (p. 17) reminding scholars of the need for a more nuanced and contextualized view of educational technology. In their article entitled, Remote from What? Perspectives of Distance Learning Students in Remote Rural Areas of Scotland, Macintyre and Macdonald (2011) argue the:

focus on online learning within distance education as the best solution for all learners is obscuring our understanding of the range of contexts in which distance learning is experienced. (p. 1)

Their work, as well as Pyles (2016), Staley (2017), Wargo et al. (2020), and Wake (2012) highlight complex, heterogeneous, and everpresent shifting rural education contexts that are often overlooked.

\section{Implications for future research}

To move beyond the possible toward the actual (Selwyn, 2010), more scholarly insights about how technology-infused teaching and learning are optimized in rural places for the betterment of rural places are needed. Curiously, despite almost 40 years of researchers describing the promise of positive change in rural education alongside technological development, as shown from the earliest (Wirth et al., 1983) to the most recent (Powers et al., 2020), studies reviewed very few concrete and detailed examples of how change for the better (beyond what could be described as results illustrating what's possible) were shared. Education technology scholarship has demonstrated that the use of education technology is associated with increased engagement (Bebell \& O'Dwyer, 2010); however, many questions remain about engagement (Henrie et al., 2015), especially once the newness wears off.

Many of the studies within this review discussed barriers. Although it is important to acknowledge these barriers, there is a need for future research to explore power dynamics and issues of equity associated with rural schooling instead of merely pointing out what rural schools do not have as compared to their non-rural counterparts. Otherwise, elevating technology as part of the solution may just be further contributing 
to what Biddle and Azano (2016) described as "the century-long trend of looking only at problems of rural communities, rather than at the opportunities" (p. 314) perpetuating the "rural schools' problem." If we choose not to study the impacts of technology from an ecological sense (Postman, 1989; Zhao, 2010), large elements of rural education affected by technological change may remain hidden to the detriment of rural people and communities.

Very few researchers (Ruopp, 1993 being an example of an exception) used a holistic frame to explore the rural educational experience with technology. Instead, researchers focused on one type of technology and how rural actors related to it for a specific purpose, producing insights that could be likened to applying a spotlight to illuminate one small area of an otherwise dark stage. By weaving the language about their "spotlight" area with descriptions of rural deficits without zooming out to "floodlight" researchers have inadvertently masked the complexity and nuance of rurality. Combined, the 52 studies reviewed metaphorically could be described as a dark stage with many small spotlights leaving many opportunities to illuminate the entire stage in future studies. According to Biddle and Azano (2016), the field must "reevaluate education's relationship to marginalized places and spaces in a holistic and inclusive way" to allow for "geographic realities to foreground our understanding of the world" ( $p$. 316).

What is needed is a heightened level of humble reflection about what the purpose of using technology as part of rural schooling is, who decides, under what conditions, in ways that support equitable and sustainable systems for teaching and learning. As well there is a need to illuminate opportunities for learning in rural places that are not just better because it has happened using a form of technology most likely developed in a non-rural place (i.e., Silicon Valley) by those historically less marginalized (i.e., white males) equating to some more "developed" form of education., but instead because it amplifies high quality, deep learning experiences for learners which matter for all.

Previous scholarship illustrates how factors such as social-economic status, ethnicity, and gender matter for how technology is used. For example, "students within low-SES schools are more likely to use drill-and-practice software, whereas students in high-SES schools are more likely to use productivity software for educational purposes" (Ritzhaupt et al., 2013, p. 292). Such differences are problematic anywhere, but in light of rural teacher shortages, they may be particularly problematic for rural communities. As learners everywhere face global and local challenges, scholars can and must assist rural practitioners, policymakers, and advocates towards making informed decisions about technology in ways that benefit rural learners and communities.

Building upon the past several decades of research and practice, it is time for the field to move towards confronting questions of equity and justice by exploring not only the opportunities and challenges associated with education technology. Many questions remained unanswered about how such use and access are intertwined with policy, economics, and geography. How does the technological layer assist (or perpetuate) rural education inequalities? What is saved (or lost) when technology is gained? How can technology be leveraged in rural education spaces and places for what Howard et al. (2020) describe as "teaching and learning based on sustainable flourishing communities and well-being for all" (p. 9)? Answers to such questions can contribute to assisting what Biddle and Azano (2016) highlight as the need to "find the intersection of rural realities with diverse sociospatial realities in the context of 21 st-century globalization" (p. 317).

\section{Towards a more critical perspective: Avoiding dichotomous traps}

To begin to answer these questions, a critical perspective (Selwyn, 2010) is needed to avoid a dichotomous trap - purely 'hard' technological determinism or techno-skeptic perspectives (e.g., rhetoric that pits in-person schooling against online options). Some older works explicitly acknowledged that schools and districts are complex social organizations within unique and shifting places have much to offer still to this day. Despite the fact that the technologies described in these articles have long been replaced by newer ones, they illustrate the need to acknowledge the uniqueness of rural contexts. As Williamson et al. (2020) point out, there is a need to confront "questions and challenges of the political economy of edtech, digital inequalities, spaces and futures of learning, and datafication of education" (p. 114).

Curiously, several conceptual articles that did not meet this study's criteria related to having a clear methods section (including the 1993 new telecommunications mediums issue of JRRE aside from one article - Ruopp; Hannum 2009b; Howley \& Howley, 1995; Sundeen \& Sundeen, 2013) support the need for more critical scholarship about education technology. These no doubt aid in moving the scholarly conversation about the role of technology in rural education forward.

\section{Conclusion: Chipping Away at Technochauvinism and Amplifying Rural Strengths}

The aim of this review, which offered a descriptive and narrative synthesis of four decades of rural education research about technology, was 
to simply serve the field. The three storylines that emerged, especially in light of events associated with COVID-19, explicate the need to do so in ways that offer insights that matter for equality, truth, and justice. Rural schools are some of the only social institutions in rural communities supporting youth (Biddle \& Azano, 2016). Uneven power structures, a lack of resources, and deficit orientations still deserve scholarly attention. In many ways, this study begins to break down the dangerous trend of adding technology to rural schooling to solve what Biddle and Azano (2016) point out has happened since the inception of rural schooling itself - assume rurality is a problem. In part, this means the field must become more aware of technochauvinism: "the idea that technological solutions are superior" (Broussard, 2020, para 8).

As algorithms and equipment that disperse them are increasingly deployed to automate teaching and learning functions, such as those highlighted by Broussard (Sept 8th, 2020) in her opinion article titled "When Algorithms Give Real Students Imaginary Grades" come to light, there is a critical need to acknowledge what technology cannot solve. Brussard notes:

Computers are excellent at doing math, but education is not math - it's a social system. And algorithmic systems repeatedly fail at making social decisions. Algorithms can't monitor or detect hate speech, they can't replace social workers in public assistance programs, they can't predict crime, they can't determine which job applicants are more suited than others, they can't do effective facial recognition, and they can't grade essays or replace teachers.

Rural education spaces and places are a complex entanglement of technical and social forces. Curiously, language about why to use technology is unsettling in a way similar to that which authors used to describe rural school consolidation. In this review, some authors (e.g., Shaft, 2006) discuss the potential for distance education to potentially combat school consolidation; however, as technologies complicate conceptualizations of time and space, a more nuanced view of how best to access and use technology as part of the educational experience in specific rural places is needed. A great opportunity lies ahead to support the practice of using educational technology in rural locales in ways that assist learners and educators in place for place.

In 2010, Budge asked, "Why shouldn't rural kids have it all?" Rapid actions to close in-person schooling all over the country elevated the notion that in many places, urban and rural alike, despite having some technology, most educators and learners in the United States do not have it all. Works in this review, such as Staley (2017), Wake (2012), and Pyles (2016) are examples that illustrate the potential for voices in rural social spaces to be amplified with mindful use of technology in ways that elevate rural strengths.

Literature on connected work illustrates consequences and unforeseen phenomena associated with the rise of information technology in other sectors (Rushkoff, 2013; Turkle, 2011) such as work-nonwork conflict and psychological strain: perceived stress (Day et al., 2012) and overload (Klausegger, Sinkovic, \& Zou, 2007); however, it appears there is insufficient education research to conclude the same. Considering these new challenges associated with constant connectivity, we wonder whether the lessconnected positionality of rural places might be an advantage. Now, in light of the COVID-19 pandemic when many are quite frankly "Zoomed out" and rural gentrification is at an all-time high, as those in non-rural spaces flock to amenity-rich rural areas for many reasons, the need to find the creative capacity to solve novel problems and think deeply is more important than ever.

Recently, the first author had the pleasure of observing elementary students in rural North Idaho as a few education leaders started to expand their relationship with the local land trust to move learning "outside the box" in a local community forest. Although the project is in its infancy, there is a strong body of research that demonstrates the mental and physical benefits of time in nature and educators are noticing anecdotally that learners are more cognitively and behaviorally engaged in science lessons. As students experience the natural world, cognitive engagement with real-world questions is almost a given. Finding answers to these questions is an exercise in using both technology and place. The balance of an on/off approach to technology seems to be, in this sense, something that schools in remote locations have to their advantage. As technology most likely becomes further intertwined with rural education, hopefully, scholars, practitioners, advocates, and policymakers elevate the best of what technology and place have to offer.

\title{
References
}

\footnotetext{
* Article included in the narrative review
}

\author{
*Alexander, G.C. (2003). Reaching Out to Rural \\ Schools: University-Practitioner Linkage
}


Through the Internet. Journal of Technology and Teacher Education, 11 (2), 321-330.

Altheide, D. L. (1987). Ethnographic content analysis. Qualitative Sociology, 10(1), 65-77. doi:10.1007/ BF00988269

Anderson, R. E., \& Becker, H. J. (2001). School investment in instructional technology: Teaching, learning, and computing. 1998 National Survey (Tech. Rep. No. 8). Irvine, CA: University of California, Center for Research on Information Technology and Organizations; Minneapolis, MN: University of Minnesota.

*Barker, B. (1986). The role of the microcomputer in rural schools. The Rural Educator, 8(1), 1-3.

*Barker, B. \& Hall, R.F. (1994). Distance

Education in Rural Schools: Technologies and Practice. Journal of Research in Rural Education, 10(2), 126-128. https://citeseerx.ist.psu.edu/viewdoc/download ?doi=10.1.1.527.9954\&rep=rep1\&type=pdf

Barzilai-Nahon, K. (2006). Gaps and bits: Conceptualizing measurements for digital divide/s. The Information Society, 22(5), 269278. https://doi.org/10.1080 /01972240600903953

Bebell, D., \& O’Dwyer, L. (2010). Educational Outcomes and Research from 1:1 Computing Settings. The Journal of Technology, Learning and Assessment, 9(1). https://ejournals.bc.edu /index.php/jtla/article/view/1606

*Beck, D., Maranto, R., \& Shakeel, M. D. (2018). Does Rural Differ? Comparing Parent and Student Reasons for Choosing Cyber Schooling. The Rural Educator, 37(3). https://doi.org/10.35608/ruraled.v37i3.243

Benner, P. (1994). Interpretive phenomenology: Embodiment, caring, and ethics in health and illness. Sage Publishers.

Biddle, C., \& Azano, A. P. (2016). Constructing and Reconstructing the "Rural School Problem": A Century of Rural Education Research. Review of Research in Education, 40(1), 298-325. https://doi.org/10.3102 /0091732X16667700

Biddle, C., Sutherland, D.H., \& McHenry-Sorber, E. (2019). On resisting "awayness" and being a good insider: Early career scholars revisit Coladarci's swan song a decade later. Journal of Research in Rural Education, 35(7), 1-16. https://doi.org/10.26209/jrre3507

Bourdieu, P. (1990). The logic of practice. Stanford university press.

Bourdieu, P., \& Wacquant, L. J. (1992). An invitation to reflexive sociology. University of Chicago press.
Broussard, M. (2020, September 8). Opinion | When Algorithms Give Real Students Imaginary Grades. New York Times. https://www.nytimes.com/2020/09/08/opinion/ international-baccalaureate-algorithmgrades.html?auth=loginemail\&login=email\&smid=tw-share

Brockmeier, L. L., Sermon, J. M., \& Hope, W. C. (2005). Principals' relationship with computer technology. NASSP Bulletin, 89(643), 4563. https://doi.org/10.1177/019263650508964305

Bruwelheide, J. H. (1984). Computer literacy: A current review of the literature. The Rural Educator, 5(3), 6-10.

Budge, K. (2010). Why shouldn't rural kids have it all? Place-conscious leadership in an era of extralocal reform policy. Education Policy Analysis Archives, 18(1), 1-22. https://doi.org/10.14507/epaa.v18n1.2010

Burton, M., Brown, K, \& Johnson, A. (2013). Storylines about rural teachers in the United States: A narrative analysis of the literature. Journal of Research in Rural Education, 28(12), 1-18. http://jrre.psu.edu/articles/2812.pdf

*Cady, J. \& Rearden, K. (2009). Delivering Online Professional Development in Mathematics to Rural Educators. Journal of Technology and Teacher Education, 17(3), 281-298. https://www.learntechlib.org/p/28295/

*Chance, E.W. (1996). Electronic Field Trips: Using Technology to Enhance Classroom Instruction. The Rural Educator, 17(3), 11-13.

*Clark, L., Majumdar, S., Bhattacharjee, J., \& Hanks, A.C. (2015) Creating an Atmosphere for STEM Literacy in the Rural South Through Student-Collected Weather Data, Journal of Geoscience Education, 63(2), 105-115. https://doi.org/10.5408/13-066.1

Cuban, L. (2001). Oversold and underused: Computers in the classroom. Harvard University Press.

*Cullen, T. A., Brush, T. A., Frey, T. J., Hinshaw, R. S., \& Warren, S. J. (2006). NCLB Technology and a Rural School. The Rural Educator, 28(1). https://doi.org/10.35608/ruraled.v28i1.485

*Cifuentes, L., Maxwell, G., \& Bulu, S. (2011). Technology Integration Through Professional Learning Community. Journal of Educational Computing Research, 44(1), 59-82. https://doi.org/10.2190/EC.44.1.d

Coladarci, T. (2007). Improving the yield of rural education research: An editor's swan song. Journal of Research in Rural Education, 22(3), 1-9. http://www.jrre.psu.edu/articles/22-3.pdf 
*Collier, M., Kingsley, K., Ovitt, B., Lin, Y., \& Benavidez, J. (2017) Fostering collaboration with families of children with disabilities: Online professional development for $\mathrm{K}-12$ teachers, The Teacher Educator, 52(2), 138154. https://doi.org/10.1080/08878730 .2016 .1273421

Corbett, M. (2015). Towards a rural sociological imagination: Ethnography and schooling in mobile modernity. Ethnography and education, 10(3), 263-277. https://doi.org/10.1080 /17457823.2015.1050685

Day, A., Paquet, S., Scott, N., \& Hambley, L. (2012). Perceived information and communication technology (ICT) demands on employee outcomes: The moderating effect of organizational ICT support. Journal of Occupational Health Psychology, 17(4), 473491. https://doi.org/10.1037/a0029837

de Certeau, M. (1984). The practice of everyday life (trans. S. Rendall). University of California Press.

*de la Varre, C., Irvin, M.J., Jordan, A.W., Hannum, W.H., \& Farmer, T.W. (2014). Reasons for student dropout in an online course in a rural $\mathrm{K}-12$ setting, Distance Education, 35(3), 324-344, https://doi.org/10.1080/01587919.2015.955259

*de la Varre, C., Keane, J., \& Irvin, M. J. (2011). Dual perspectives on the contribution of onsite facilitators to teaching presence in a blended learning environment. The Journal of Distance Education/Revue de l'Éducation à Distance, 25(3). http://www.ijede.ca/index.php/jde

*de la Varre, C., Keane, J., \& Irvin, M. J. (2010). Enhancing online distance education in small rural US schools: A hybrid, learner-centred model. ALT-J, 18, 193-205. https://doi.org/10.1080/09687769.2010.529109

Dolan, J. E. (2016). Splicing the divide: A review of research on the evolving digital divide among K-12 students. Journal of Research on Technology in Education, 48(1), 16-37. https://doi.org/10.1080/15391523.2015.110314 7

*Elam, M. E., Donham, B. L., \& Solomon, S. R. (2012). An engineering summer program for underrepresented students from rural school districts. Journal of STEM Education: Innovations \& Research, 13(2), 35-44. https://www.jstem.org/jstem/index.php/JSTEM /article/view/1619

*Erickson, J. (1997). Building a Community of Designers: Restructuring Learning through Student Hypermedia Design. Journal of
Research in Rural Education, 13(1), 5-27. https://jrre.psu.edu/sites/default/files/201908/13-1_5.pdf

*Erion, R.L. \& Moeller, L. (1991). A Computer Literacy Course: A Needs Assessment. The Rural Educator, 12(3), 4-8.

Every Student Succeeds Act, 20 U.S.C. $\$ 6301$ (2015). https:www.congress.gov/114/plaws/pub195/PL AW-114pub195.pdf

Farmer, F. L. (1997). Rural, Definition of. In G. A. Goreham (Ed.), Encyclopedia of rural America: The land and people (pp. 623-626). ABCCLIO, Inc

Federal Communications Commission. (2020). 2018 broadband deployment report. https://docs.fcc.gov/public/attachments/FCC20-50A1.pdf

Fink, A. (2019). Conducting Research Literature Reviews. Sage.

*Frantom, C. G., Green, K. E., \& Hoffman, E. R. (2002). Measure Development: The Children's Attitudes toward Technology Scale (CATS). Journal of Educational Computing Research, 26(3), 249-263.

https://doi.org/10.2190/DWAF-8LEQ-74TNBL37

*García-Villada, E. (2011). I () Spanish: K-8 Attitudes toward Learning Spanish with Computers. Hispania, 94(1), 184-207. https://www.muse.jhu.edu/article/424437.

Goals for 2000: Educate America Act, Pub. L. No. 103-227, 108 Stat. 125 (1994, March 31). https://www.govinfo.gov/content/pkg/STATU TE-108/pdf/STATUTE-108-Pg125.pdf

No Child Left Behind (NCLB) Act of 2001, Pub. L. No. 107-110, 115 Stat. 1425 (2002, January 8). http://www.ed.gov/policy/elsec/leg/esea02/ind ex.html

*Griswold, P. (1984). Computer awareness and attitudes of prospective rural teachers. The Rural Educator, 5, 11-15.

Hannum, W. (2007). When computers teach: A review of the instructional effectiveness of computers. Educational Technology, 47(2), 513. http://www.jstor.org/stable/44429482

* Hannum, W. H., Irvin, M. J., Banks, J. B., \& Farmer, T. W. (2009a). Distance education use in rural schools. Journal of Research in Rural Education, 24(3), 1-15. https://jrre.psu.edu/sites/default/files/201908/24-3.pdf

Hannum, W. (2009b). Reflections: Moving distance education research forward. Distance Education, 30: 171-173. https://doi.org/10.1080/01587910902846020 
Hannum, W., Irvin, M., Pui-Wa, L., \& Farmer, T. (2008). Effectiveness of using learner-centered principles on student retention in distance education courses in rural schools. Distance Education, 29(3), 211- 229. https://doi.org/10.1080/01587910802395763

*Hawkes, M., Halverson, P. \& Brockmueller, B. (2002). Technology Facilitation in the Rural School: An Analysis of Options. Journal of Research in Rural Education, 17(3), 162. https://jrre.psu.edu/sites/default/files/201908/17-3_4.pdf

*Hawkes, M. \& Good, K. (2000). Evaluating Professional Development Outcomes of a Telecollaborative Technology Curriculum. The Rural Educator, 21(3), 5-11.

Henrie, C., Halverson, L., \& Graham, C. (2015). Measuring student engagement in technologymediated learning: A review. Computers and Education, 90(1), 36-53. https://doi.org/10.1016/j.compedu.2015.09.005

Hess, F. (2018). Why we get tech-enabled personalized learning wrong. Education Next. https://www.educationnext.org/get-techenabled-personalized-learning-wrong/.

*Howley, A., \& Howley, C. (2008). Planning for technology integration: Is the agenda overrated or underappreciated. Educational Planning, 17(1), 1-17. https://isep.info/wpcontent/uploads/2015/03/171_1PlanningforTechnology.pdf

*Howley, A., \& Howley, C. (1994). Receptivity to Telecommunications among K-12 Teachers in a Rural State: Results of a West Virginia Survey. The Rural Educator, 17(1), 7-14.

Howley, C., \& Howley, A. (1995). The power of babble: Technology and rural education. Phi Delta Kappan, 77(2), 126-131. https://files.eric.ed.gov/fulltext/ED382437.pdf

Howley, C. (1993). A Territorial Imperative: The Authority of the State to Reorganize Public Schools and Districts. Journal of Research in Rural Education, 9(2), 74-83. http://sites.psu.edu/jrre/wpcontent/uploads/sites/6347/2014/02/9-2_8.pdf

*Howley, A., Wood, L., \& Hough, B. (2011). Rural elementary school teachers' technology integration. Journal of Research in Rural Education, 26(9). http://jrre.psu.edu/ articles/26-9.pdf

*Hunt-Barron, S., Tracy, K. N., Howell, E., \& Kaminski, R. (2015). Obstacles to enhancing professional development with digital tools in rural landscapes. Journal of Research in Rural Education, 30(2), 1-14. https://jrre.psu.edu/sites/default/files/201908/30-2.pdf

*Irvin, M.J., Hannum, W.H., de la Varre, C., Farmer, T.W., \& Keane, J. (2012) Factors related to rural school administrators' satisfaction with distance education, Distance Education, 33:3, 331-345. https://doi.org/10.1080/01587919.2012.723163

*Irvin, M.J., Hannum, W.H., Varre, C., Farmer, T.W. (2010). Barriers to Distance Education in Rural Schools. Quarterly Review of Distance Education, 11(2), 73-90. http://www.infoagepub.com/index.php?id=89 $\& \mathrm{i}=51$

*Irvin, M. J., Hannum, W. H., Farmer, T. W., Varre, C. de la, \& Keane, J. (2009). Supporting Online Learning for Advanced Placement Students in Small Rural Schools. The Rural Educator, 31(1). https://doi.org/10.35608/ruraled.v31i1.440

* Kalonde, G. (2018). Media in Rural Schools. A Case of a Rural High School trying to use iPads in Class Abstract. The Rural Educator, $38(3)$. https://doi.org/10.35608/ruraled.v38i3.218

Klausegger, C., Sinkovics, R., \& Zou, H. (2007). Information overload: A cross-national investigation of influence factors and effects. Marketing Intelligence \& Planning, 25(7), 691-718. https://doi.org/10.1108/02634500710834179

*Krall, R., Straley, J., Shafer, S., \& Osborn, J. (2009). Hands-on at a Distance: Evaluation of a Temperature and Heat Distance Learning Course. Journal of Science Education and Technology, 18(2), 173-186. https://doi.org/10.1007/s10956-008-9142-2

*Lahman, M. K. E., D'amato, R. C., Stecker, S., \& Mcgrain, E. (2006). Addressing the Shortage of Rural School Psychologists via Technology: Using Candidate Qualitative Interviews to Inform Practice. School Psychology International, 27(4), 439-461. https://doi.org/10.1177/0143034306070429

*Laho, N.S. (2019). Enhancing School-Home Communication through Learning Management System Adoption: Parent and Teacher Perceptions and Practices. School Community Journal, 29, 117-142. http://www.adi.org/journal/2019ss/LahoSS201 9.pdf

Leu, D. J., Forzani, E., Rhoads, C., Maykel, C., Kennedy, C., \& Timbrell, N. (2015). The new literacies of online research and comprehension: Rethinking the reading achievement gap. Reading Research 
Quarterly, 50(1), 37-59.

https://doi.org/10.1002/rrq.85

Lynch, J. (2015). Researching with heart in edtech: What opportunities does the socially indeterminate character of technological artifacts open up for affirming emergent and marginalized practices? In S. Bulfin, N. Johnson \& C. Bigum (Eds.), Critical perspectives on technology and education (pp. 141-162). Palgrave Macmillan.

Macintyre, R., \& Macdonald, J. R. (2011). 'Remote from what?' Perspectives of distance learning students in remote rural areas of Scotland. The International Review of Research in Open and Distributed Learning, 12(4), 1-16. https://doi.org/10.19173/irrodl.v12i4.847

*Mann, B., Kotok, S., Frankenberg, E., Fuller, E., \& Schafft, K. (2018). Choice, Cyber Charter Schools, and the Educational Marketplace for Rural School Districts. The Rural Educator, 37(3). https://doi.org/10.35608/ruraled.v37i3.248

Matthewman, S. (2011). Technology \& social theory. Palgrave Macmillan.

*McGinnis, J.R., Simmons, P., Atwater, M.M. et al. (1996). Beliefs and perceived needs of rural $\mathrm{K}-12$ teachers of science toward the uses of computing technologies. Journal of Science Education and Technology 5, 111-120. https://doi.org/10.1007/BF01575151

McLeod, S., \& Dulsky, S. (2021). Resilience, reorientation, and reinvention: School leadership during the early months of the COVID-19 pandemic. Frontiers in Education https://doi.org/10.3389/feduc.2021.637075

*Monhardt, R. M., \& Monhardt, L. (1998). Facilitating Science Literacy in a Rural School. Bulletin of Science, Technology \& Society, 18(1), 47-53. https://doi.org/10.1177/027046769801800107

*Naizer, G., Hawthorne, M. J., \& Henley, T. B. (2014). Narrowing the gender gap: Enduring changes in middle school students' attitude toward math, science and technology. Journal of STEM Education: Innovations and Research, 15(3), 29-34. https://jstem.org/jstem/index.php/JSTEM/articl e/view/1825/1623

National Center for Education Statistics (NCES). (2019). Table 236.20: Total expenditures for public education and secondary education and other related programs, by function and subfunction: Selected years, 1990-91 through 2015-16. https://nces.ed.gov/programs/digest/d18/tables/ dt18_236.20.asp?current=yes
National Commission on Excellence in Education. (1983). A nation at risk. http://files.eric.ed.gov/fulltext/ED226006.pdf

National Rural Education Association. (2016). Research agenda-2016-2021. https://drive.google.com/file/d/0B6jy_ymJ61PcEhlbmxPZU5XLTg/view?resourceke $\mathrm{y}=0-\mathrm{R}-11 \mathrm{OhSAvRkwn6WCAGw27A}$

No Child Left Behind (NCLB) Act of 2001, Pub. L. No. 107-110, 115 Stat. 1425 (2002, January 8). http://www.ed.gov/policy/elsec/leg/esea02/ind ex.html.

Office of Education Technology. (2017). Reimagining the role of technology in education: 2017 national education technology update. U.S. Department of Education. https://tech.ed.gov/files/2017/01/NETP17.pdf

Ogburn, W. (1922). Social Change with Respect to Culture and Original Natures. Huebsch.

Petticrew, M., \& Roberts, H. (2006). Systematic reviews in the social sciences: a practical guide. Blackwell.

Pickering, A. (1995). The Mangle of Practice: Time, Agency, and Science. University of Chicago Press.

*Plopper, B. L., \& Conaway, A. F. (2013). Scholastic Journalism Teacher Use of Digital Devices and Social Networking Tools in a Poor, Largely Rural State. Journalism \& Mass Communication Educator, 68(1), 50-68. https://doi.org/10.1177/1077695812472895

Popay, J., Roberts, H., Sowden, A., Petticrew, M., Arai, L., Rodgers, M.,... Duffy, S., (2006). Guidance on the Conduct of Narrative Synthesis in Systematic Reviews. ESRC. DOI: 10.13140/2.1.1018.4643=

Postman, N. (1998, March 27). Five things we need to know about technological change. In Proceedings of The New Technologies and the Human Person: Communicating the Faith in the New Millennium, Denver, CO.

*Powers, J. R., Musgrove, A. T., \& Nichols, B. H. (2020). Teachers Bridging the Digital Divide in Rural Schools with 1:1 Computing. The Rural Educator, 41(1), 61-76. https://doi.org/10.35608/ruraled.v41i1.576

*Pyles, D. G. (2016). Rural media literacy: Youth documentary videomaking as a rural literacy practice. Journal of Research in Rural Education, 31(7), 1-15. https://jrre.psu.edu/sites/default/files/201908/31-7.pdf

Reeves, C. (2003). Implementing the No Child Left Behind Act: Implications for rural schools and districts. Educational Policy Publications. https://files.eric.ed.gov/fulltext/ED475037.pdf 
Reid, J.-A., Green, B., Cooper, M., Hastings, W., Lock, G., \& White, S. (2010). Regenerating Rural Social Space? Teacher Education for Rural-Regional Sustainability. Australian Journal of Education, 54(3), 262-276. https://doi.org/10.1177/000494411005400304

*Richardson, J.W., \& McLeod, S. (2011). Technology Leadership in Native American Schools. Journal of Research in Rural Education, 26(7). http://jrre.psu.edu/articles/26-7.pdf

Ritzhaupt, A., Liu, F., Dawson, K., \& Barron, A. (2013). Differences in Student Information and Communication Technology Literacy Based on Socio-Economic Status, Ethnicity, and Gender. Journal of Research on Technology in Education. 45, 291-307. https://doi.org/10.1080/15391523.2013.107826 07

Roberts, E., Anderson, B.A., Skerratt, S. and Farrington, J. (2017). A review of the ruraldigital policy agenda from a community resilience perspective. Journal of Rural Studies, 54, 372-385. https://doi.org/10.1016/j.jrurstud.2016.03.001

*Ruopp, R., Pfister, B.D., \& Shahaf, G. (1993). Supporting Teachers with Telecommunication: The LabNetwork. Journal of Research in Rural Education, 9(1), 43-46. https://jrre.psu.edu/sites/default/files/201908/9-1_1.pdf

Rushkoff, D. (2013). Present shock: when everything happens now (p. 67). Penguin Group.

Sassen, S. (2002). Towards a sociology of information technology. Current Sociology, 50(3): 365-388. https://doi.org/10.1177/0011392102050003005

Selwyn, N. (2015). Technology and education-why it's critical to be critical. In S. Bulfin, N. Johnson \& C. Bigum (Eds.), Critical Perspectives on Technology and Education (pp. 245-255). New York, NY: Palgrave Macmillan.

Selwyn, N. (2010). Looking beyond learning: note toward the critical study of educational technology. Journal of Computer Assisted Learning, 26, 65-73. https://doi.org/10.1111/j.13652729.2009.00338.x

*Singer, G., Sowers, J.-A., \& Irvin, L. K. (1986). Computer-Assisted Video Instruction for Training Paraprofessionals in Rural Special Education. Journal of Special Education Technology, 8(1), 27-34. https://doi.org/10.1177/016264348600800104
*Schafft, K. A., Alter, T. R., \& Bridger, J. C. (2006). Bringing the community along: A case study of a school district's information technology rural development initiative. Journal of Research in Rural Education, 21(8), $1-10$.

https://jrre.psu.edu/sites/default/files/201908/21-8.pdf

*Staley, B. (2018). Journeying Beyond: Digital Storytelling with Rural Youth. The Rural Educator, 38(2). https://doi.org/10.35608/ruraled.v38i2.225

*Stammen, R.M. (1992). Computer Conferencing: Perspectives of Rural school Administrators. The Rural Educator, 13(2), 24-27.

*Summerville, J., Johnson, C.S. (2006). Rural Creativity: A Study of District Mandated Online Professional Development. Journal of Technology and Teacher Education, 14(2), 347-361. https://www.learntechlib.org/primary/p/5717/

Sundeen, T. H., \& Sundeen, D. M. (2013). Instructional technology for rural schools: Access and acquisition. Rural Special Education Quarterly, 32(2), 8-14. https://doi.org/10.1177/87568705130-3200203

Turkle, S. (2011). Alone together: Why we expect more from technology and less from each other. Basic Books.

*Tyler-Wood, T.L., Cockerham, D., \& Johnson, K.R. (2018). Implementing new technologies in a middle school curriculum: A rural perspective. Smart Learning Environments 5(22), 1-16.

https://slejournal.springeropen.com/articles/10. 1186/s40561-018-0073-y

U.S. Department of Education. (2010). Transforming American education: Learning powered by technology. http://www.ed.gov/sites/default/files/ netp2010.pdf

*Wake, D. (2012). Exploring rural contexts with digital storytelling. The Rural Educator, 33(3), 23- 37. https://doi.org/10.35608/ruraled.v33i3.409

* Wargo, E., Carr-chellman, D., Budge, K., \& Canfield-Davis, K. (2021). On the digital frontier: Stakeholders in rural areas take on educational technology and schooling. Journal of Research on Technology in Education 53(2) ,140-158. https://doi.org/10.1080/15391523.2020.176075 3

*Watson, W.R., Mong, C.J. \& Harris, C.A. (2011). A case study of the in-class use of a video game for teaching high school history. 
Computers \& Education, 56(2), 466-474.

https://www.learntechlib.org/p/67179/

Williamson, B., Eynon, R., and Potter, J. (2020).

Pandemic politics, pedagogies and practices:

digital technologies and distance education during the coronavirus emergency. Learning, Media and Technology, 45(2), 107-114. https://doi.org/10.1080/17439884.2020.176164 1

*Wirth, P. A., Style, S.W., \& Cole, J.T. (1983).

The Need for Inservice Training in
Instructional Technology for Special Education Personnel in Small Rural School Districts. Journal of Special Education Technology, 6(1), 25-29.

Zhao, Y. (2010). Preparing Globally Competent Teachers: A New Imperative for Teacher Education. Journal of Teacher Education, 61(5), 422-431.

https://doi.org/10.1177/0022487110375802

\section{Authors:}

Elizabeth S. Wargo is an Assistant Professor of Education Leadership at the University of Idaho. Contact: ewargo@uidaho.edu

Jeff Simmons is a doctoral student at the University of Idaho and the Director of Supervision and Instruction for the Idaho Digital Learning Alliance. Contact: jsimmons@uidaho.edu

\section{Suggested Citation:}

Wargo, E. S. \& Simmons, J. (2021). Technology storylines: A narrative analysis of the rural education research. The Rural Educator, 42(2), 35-50, https://doi.org/ 10.35608/ruraled.v42i2.1240 to

C 2021. This work is licensed under a CC BY 4.0 license. See https://creativecommons.org/licenses/by/4.0/ 